\title{
INFLUENCE OF DOXAPRAM HYDROCHLORIDE ON RECOVERY FROM THIOPENTAL ANAESTHESIA
}

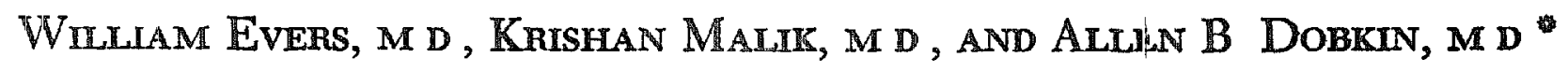

MANY DRUGS known as respiratory stımulants have been used to accelerate recovery from poisoning by barbiturates and other sedative drugs These stimulants have also been used to initiate and sustam breathing in the newborn, and to accelerate the rate of recovery from general anaesthesia Perhaps the most common practice in years past has been to add carbon dioxide inhalation at the end of an anaesthetic to accomplish this goal Even though many feel that these practices may be inherently dangerous, they are still used ${ }^{12}$

Recently, several new drugs have been developed which can augment breathing and may accelerate recovery from anaesthesia with far less likelihood of producing dangerous irritation of the gastrountestinal tract (vorniting), respiratory tract (coughing, sneezing), or neuromuscular system (muscle twitching, convulsions $)^{3-6}$ Some of these drugs are now being used effectively in the management of chronic incapacitating lung diseases, and they may be useful for reversing respiratory depression produced by analgesics ${ }^{7-10}$ Although their action is of short duration when given as a single injection, they increase the sensitivity of the respiratory centres to the arterial blood $p \mathrm{CO}_{2}$ during postanaesthetic resp1ratory depression and may be useful in this condition, especially if given as a continuous infusion rather than as a single injection ${ }^{36} 11$

A drug of this kmd, which was recently introduced, is 1-ethyl-4(2-morpholinoethyl) -3,3-diphenyl-2 pyrrolidinone hydrochlonde hydrate (Doxapram ${ }^{12}$ It is prepared as a 2 per cent stable aqueous solution having a $\mathrm{pH}$ of 35 to 50 , which is compatible with 5 or 10 per cent dextrose in water and with 09 per cent saline, but is not compatible with any solutions which are alkaline Radioactive carbontagged studies of Doxapram in dogs showed that 29 per cent of the $\mathrm{C}^{14}$ is excreted in the faeces in the first 48 hours and no Doxapram in the unchanged form is found in the urine

This study was undertaken to delermine whether Doxapram effectively shortens the recovery time from thropental anaesthesia in dogs and to evaluate its efficacy for accelerating recovery from thiopental-nitrous oxade anaesthesia when used following a relatively standard clinical operation in women The influence of Doxapram on the respiratory and cardiovascular systems in the immediate postanaesthetic periods was also evaluated clinically

Methylphenidate and $d$-amphetamine were tested in the animals for comparison with Doxapram, but they were not used in the clinical study because the former frequently causes gastrointestinal disturbances, and the latter causes cardiac arrhythmias

\footnotetext{
From the Department of Anesthesiology, State Unuversity of New York, Upstate Medical Center, Syracuse, N Y 13210
} 


\section{METHODS}

\section{Animal Study}

Cross-over experiments were performed four times, at weekly intervals with Doxapram, $d$-amphetamine, and methylphenidate, using 10 mongrel dogs of comparable age and size ( 13 to $25 \mathrm{~kg}$, mean $21 \mathrm{~kg}$ ) Prior to each test the dogs were weighed after a 12-hour fast In every experiment, each dog recelved 25 $\mathrm{mg} / \mathrm{kg}$ thiopental in a 25 per cent solution, injected intravenously in a forepaw vein at the approximate rate of $150 \mathrm{mg}$ per minute This was followed immediately, in alternate experiments, by injection of one of the test drugs The dose selected for the test drug was based on the therapeutic range of usefulness Immediately after injection, the dog was placed on the floor of the laboratory and allowed to recover without being disturbed or stimulated The recovery time of each animal was recorded as the time which elapsed from the beginning of the injection until the dog lifted its head, and then until it attempted and was able to stand on all four paws without collapsing As soon as a dog recovered, it was removed from the room so that it would not disturb the remaining dogs

\section{Clinical Study}

Female patients, scheduled for elective uterine dulation and curettage, who were in good general health and in the age range of 17 to 50 years, were selected as subjects for the tests If the anaesthetic course was not smooth, or if the patient did not have a tidal volume of at least $300 \mathrm{ml}$ as determined by a Wright respirometer, at the termination of the anaesthetsc, but before the administration of Doxapram, the patient was not included in the study

Premedication consisted of atropine or scopolamine 0 4-05 mg, $1 \mathrm{~m}$, administered 30-45 minutes pror to anaesthesia Induction was achieved with thiopental 25 per cent solution administered intlavenously through a three-way stopcock connected to an intravenous infusion of $500 \mathrm{c} \mathrm{c} 5$ per cent dextrose in water A test dose of $75-100 \mathrm{mg}$ of thiopental was given After 1 minute, the patient was asked to look at the celling and count aloud during the slow injection of thiopental ( $25 \mathrm{mg} / \mathrm{sec}$ ) When the patienl stopped countung and/or closed her eyes and wouldn't open them when requested to do so, a face mask was applied and nitrous oxide-oxygen mixture ( 6 litres $/ 2$ litres) was administered using a semiclosed method and assisted breathing A second dose of thopental, equal to the total induction dose, was then injected at the same rate When abdominal relaxation was required to faciltate bimanual pelvic examination, a small dose of succinylcholine was administered intravenously Respuratory rate, blood pressure, and pulse rate were recorded throughout the procedure

At the termination of the surgical procedure, the patient's 11dal volume was measured by a Wright respirometer, along with the other vital signs Then, an intravenous infusion of Doxapram 01 per cent solution in 5 pei cent dextrose in water was begun by connectung it to the existent intravenous infusion val the three-way stopcock It was previously decided that $400 \mathrm{mg}$ would be the maximum dose of Doxapram administered at the rate of $133 \mathrm{mg}$ per minute

Thereafter, vital signs were recorded at 1 minute intervals until the patient was fully recovered from the anaesthetic, as evidenced by her answering questions and 
executing verbal commands ${ }^{2,13}$ The Doxapram intusion was discontinued when the desired end point was reached and the patient was then taken to the recovery room where another reading of thdal volume, respuratory rate, blood pressure, and pulse was taken, usually within 5 minutes after Doxapram infusion was stopped. All patients were observed carefully during theur stay in the recovery room for 1-2 hours postoperatively to determine the occurrence of side-effects.

\section{RESULTS}

The responses to Doxapram, $d$-amphetamine, and methylphenidate in dogs are summarized in Table I No untoward effects occurred following injection of the analeptics, and each invariably caused an appreciable reduction in the recovery time from thiopental anaesthesia The effects of Doxapram and $d$-amphetamine were essentially the same, while methylphenidate was evidently the weaker analeptic according to the dosage selected

TABLE I

EFTect of Respiratory Stimulants on Thioph ntal Recovery in Dogs

\begin{tabular}{|c|c|c|c|c|c|c|c|c|c|}
\hline & \multirow{3}{*}{$\begin{array}{c}\text { Dose } \\
(\mathrm{mg} / \mathrm{kg})\end{array}$} & \multicolumn{4}{|c|}{ Recovery time (mın) } & \multicolumn{4}{|c|}{ Recovery time (min) } \\
\hline & & \multirow{2}{*}{\multicolumn{2}{|c|}{$\frac{\text { Head up }}{\text { Mean* } S E}$}} & \multirow{2}{*}{$\begin{array}{l}\text { Differ- } \\
\text { ence } \\
(\%)\end{array}$} & \multirow{2}{*}{$\begin{array}{c}\text { Signifi- } \\
\text { cance } \\
p\end{array}$} & \multirow{2}{*}{\multicolumn{2}{|c|}{$\frac{\text { Leg", up }}{\text { Mean" S E }^{\text {"S }}}$}} & \multirow{2}{*}{$\begin{array}{c}\text { Differ- } \\
\text { ence } \\
(\%)\end{array}$} & \multirow{2}{*}{$\begin{array}{c}\text { Signifi } \\
\text { cance } \\
p \\
\end{array}$} \\
\hline & & & & & & & & & \\
\hline $\begin{array}{c}\text { Thiopental alone } \\
\text { + doxapram }\end{array}$ & $\begin{array}{l}25 \\
10\end{array}$ & $\begin{array}{l}33 \\
22\end{array}$ & $\begin{array}{l}6 \\
5\end{array}$ & 33 & $<0 \quad 01$ & $\begin{array}{l}53 \\
34\end{array}$ & $\begin{array}{l}7 \\
6\end{array}$ & 35 & $<0001$ \\
\hline Thiopental alone & 25 & 30 & 5 & 24 & $\begin{array}{l}>0001 \\
<0001\end{array}$ & 44 & 6 & 32 & $<0001$ \\
\hline $\begin{array}{l}\text { + amphetamine } \\
\text { Thiopental alone }\end{array}$ & $\begin{array}{rl}01 & 1 \\
25 & \end{array}$ & 23 & 4 & $2-15$ & $<0001$ & 30 & 7 & 32 & $<000$ \\
\hline $\begin{array}{l}\text { 1hiopental alone } \\
+ \text { methylphenidate }\end{array}$ & $\begin{array}{rl}25 & 0\end{array}$ & $\begin{array}{l}34 \\
29\end{array}$ & $\begin{array}{l}5 \\
7\end{array}$ & 15 & $<0 \quad 01$ & $\begin{array}{l}49 \\
38\end{array}$ & $\begin{array}{l}7 \\
7\end{array}$ & 22 & $<001$ \\
\hline
\end{tabular}

*Each mean time represents 20 administrations of thiopental alone or with test drug

A summary of the clmical data is shown in Table $\mathbb{I}$ The first effects of Doxapram were a rapid increase in tidal volume and respuratory rate These changes usually became apparent in less than one minute and, in all cases, before three minutes following the initiation of the Doxapram infusion Then a plateau was reached and, after about three to four minutes, there was a gradual decrease in both respuratory rate and tidal volume, with subsequent levelling off The initial increase in tidal volume "Nas usually more prominent and striking than the effect on the respiratory rate Pulmonary ventilation remained stable durng the period of observation after the infusion was discontinued In no instance did the tidal volume or respuratory rate decrease below the value noted immediately prior to the administration of Doxapram

Circulatory changes observed durnng the administration of Doxapram were not appreciable No instances of frank hyperiension occurred, a slight increase in blood pressure occurred in four patients $(>20 \mathrm{~mm} \mathrm{Hg}$ ) and an increase in heart rate occurred in only five patents ( 10 to 20 beats/minute)

Neuromuscular urritation appeared in four patients and consisted of muscular nigidity in two of the patients and mild twitching of the small muscles of the face 
TABLE II

Influence of Doxapram on Recovery Timt from Thiopental-Nitrous Oxide Anaesthesia

\begin{tabular}{|c|c|c|c|c|c|c|c|c|c|c|c|c|}
\hline & \multirow[b]{3}{*}{ Age } & \multirow{3}{*}{$\begin{array}{c}\text { Weight } \\
\text { (kg) }\end{array}$} & \multirow{3}{*}{$\begin{array}{l}\text { aesthest } \\
\text { time } \\
(\mathrm{min})\end{array}$} & \multirow{2}{*}{\multicolumn{2}{|c|}{ Pentothal }} & \multirow{2}{*}{\multicolumn{2}{|c|}{ Doxapram }} & \multicolumn{5}{|c|}{ Recovely time (min) } \\
\hline & & & & & & & & \multirow{2}{*}{$\begin{array}{l}\text { Response } \\
\text { to } \\
\text { verbal } \\
\text { com } \\
\text { mand }\end{array}$} & \multirow{2}{*}{$\begin{array}{l}\text { Sluggish } \\
\text { verbal } \\
\text { response }\end{array}$} & \multirow{2}{*}{$\begin{array}{c}\text { Alert } \\
\text { verbal } \\
\text { response }\end{array}$} & \multirow{2}{*}{$\begin{array}{c}\text { Hand } \\
\text { face } \\
\text { test }\end{array}$} & \multirow{2}{*}{$\begin{array}{l}\text { Total } \\
\text { sleeping } \\
\text { time }\end{array}$} \\
\hline & & & & $\begin{array}{l}\text { Total } \\
\text { dose }\end{array}$ & $\mathrm{mg} / \mathrm{kg}$ & $\begin{array}{l}\text { rotal } \\
\text { dose }\end{array}$ & $\mathrm{mg} / \mathrm{kg}$ & & & & & \\
\hline $\begin{array}{l}\text { Control* } \\
\quad \text { (55 patient }\end{array}$ & $\begin{array}{l}40 \\
\text { ts) }\end{array}$ & 64 & 20 & 480 & 75 & - & - & 14 & 17 & 18 & 19 & 38 \\
\hline $\begin{array}{l}\text { Controlł } \\
\text { (79 patient }\end{array}$ & $\begin{array}{l}37 \\
\text { ts) }\end{array}$ & 63 & 19 & 441 & 70 & - & - & 12 & 15 & 16 & 18 & 37 \\
\hline $\begin{array}{l}\text { Mean } \\
\quad(50 \text { patient }\end{array}$ & $\begin{array}{l}37 \\
\text { ts) }\end{array}$ & 69 & 31 & 560 & 93 & 195 & 33 & 5 & 6 & 7 & 8 & 39 \\
\hline Highest & 50 & 88 & 45 & 850 & 162 & 400 & 89 & 10 & 15 & 18 & 20 & 70 \\
\hline Lowest & 17 & 40 & 15 & 400 & 66 & 80 & 13 & 1 & 2 & 3 & 3 & 18 \\
\hline
\end{tabular}

*Previously reported (Ref 12)

†Previously reported (Ref 2 )

and hands in all four These symptoms disappeared within a few minutes after the Doxapram infusion was discontinued

Recovery from Anaesthesua

Signs of recovery from the anaesthetic followed shortly after the respiratory changes Once the Doxapram infusion was discontinued, there was no return to the hypnotic state precedıng the infusion The patients remained fully awake or slightly drowsy, but all were easlly engaged in conversation None of the patients developed sneezung or salivation durng the Doxapram infusion One patient coughed and one patient vomited during awakening

\section{Discussion}

Contunuous intravenous infusion of a dilute solution (01\%) of Doxapram was chosen over the intermittent method of intravenous injection on the basis of previously reported data, as well as our own expenence with Doxapram, because it permits minute-to-minute control of effects both desirable and undesurable, whereas a single injection of any analeptic produces an evanescent effect ${ }^{2,3} 11$

The decrease in recovery time was not statistically significant when compared to the expected recovery time following a double "sleep dose" of thiopental, since most adults "sleep" approximately 40 minutes after the injection of twice the amount of thropental which causes unconsciousness ${ }^{2,13,14}$ In the present study, the total "sleeping time" in the control and test groups was virtually the same, however, the stages of awakening appeared at a much faster pace in the latteran effect observed by others who have studied the action of Doxapram in humans recovering from thiopental as well as filom inhalational anaesthesia ${ }^{3-6}$

It is obvious, therefore, that one cannot categorically state that "awakening time" is changed by any therapeutic rneasure unless the average "sleeping time" for a given dose of an anaesthetic agent is determined first in a similar group or 
in the same group of patients Using a dose of $5 \mathrm{mg} / \mathrm{kg}$ of thiopental, the fully awake responses after 30 minutes occurred oftener if $1 \mathrm{mg} / \mathrm{kg}$ Doxapram was given than in the control group, although the difference was not striking in the study reported by Siker, Mustafa, and Wolfson ${ }^{5}$ In our study, the control groups had a much slower rate of awakenung even though the average dose of thiopental was less and the duration of anaesthesia maintenance was appreciably shorter On this basis, it is possible that the Doxapram infusion did in fact accelerate the rate of recovery

In dogs, an accelerated arousal effect by Doxapram hydrochloride is an established fact, as has been shown for virtually all analeptres that have been tested durung thiopental anaesthesia ${ }^{15-17}$ To be certain that an accelerated recovery from anaesthesia occurs in humans, one must use a test in which each patient is anaesthetized at least twice with the same dose, once with and once without an analeptic, as was done in a cross-over test in arumals

The respiratory stimulating action of Doxapram is beyond any doubt, as ev1denced by the results of this study, as well as those reported by others ${ }^{4-6}$ The increase in minute volume of breathing was due consistently to a rise in both tidal volume and respiratory rate ${ }^{45}$ The duration of the respiratory-stimulating action with Doxapram hydrochloride appeared to be long-lasting because once the patients awakened they did not lapse back into sleep with recurrence of respiratory depression This effect may be attributed to the much larger dose that can be administered without provoking undesurable reactions when a slow dilute infusion is given Such an effect can be duplicated with several of the newer analeptics ${ }^{3}$

Augmented pulmonary ventilation is the most useful effect that one may desure from use of an analeptic at the end of an anaesthetic on account of the usual problems ansing when postanaesthetic respiratory depression persists $27,8,18$ The effect on breathing is more likely to accelerate awakening after an inhalation anaesthetic than one given by the intravenous route, biccause the inhaled agent may be eliminated more rapidly An acceleration of awakening by an analeptic may also inherently augment pulmonary ventilation ${ }^{19}$

Effects of Doxapram on the cardiovascular system, as judged by changes in blood pressure and heart rate, were negligible in the patients observed and confirms similar observations by others ${ }^{4-6}$

Complications such as sneezing, salivation, coughing, and nausea and vomiting were uncommon, occurring only in 2 of the 50 patients in the present study, Four patients developed signs of central nervous system urritation, but, upon discontinuing the Doxapram infusion, there was an immediate abatement of this response Undesurable effects thus appeared to occur less frequently than with other analeptics ${ }^{2}$

The advantages and disadvantages of using pharmacological versus mechanical hyperventilation is a subject which remains controversial "1l However, pharma cological hyperventulation supplemented by oxygen inhlalation offers advantages over mechanical methods provided that the analeptic drug does not interfere with any physiological functions aside from stimulating or augmenting pulmonary ventilation As with any other method of intensive care, constant attendance by 
personnel familiar with the use of analeptic agents and full knowledge of how to manage possible neuromuscular complications remain essential

Since Doxapram appears to possess a high relative safety factor, it may be efficacious if used in the following situations postanaesthetic respiratory depression not due to excessive doses of muscle relaxants, postahaesthetic shallow breathing due to incisional pain ("splintıng"), especially after thoracic and uppei abdominal procedures, to accelerate arousal after short surgical procedures, and to augment breathing in instances of mild or moderate overdosage with central depressant drugs

It is probably wise to avoid the use of Doxapram hydrochlonde in patients with a history of epilepsy, petit mil, and other convulsive disorders and in patients with severe hypertensive cardiovascular disease

\section{StMMARY}

Cross-over experments performed in dogs showed that Doxapram hydrochlonde in a single-dose injection was as effective as $d$-amphetamine in shortening the recovery time from a standardized dose of thiopental anaesthesia and was more effective than methylphenidate in the dosages that were compared No untoward effects were observed in any of these experiments

When Doxapram hydrochloride was used in an intravenous infusion method for 50 healthy female patients following an elective dilatation and curettage of the uterus, the drug was effective for stimulatung respurations (both tidal volume and respiration rate) without producing any appreciable circulatory changes In four instances, there were signs of central nervous system irritation which subsided promptly upon discontinuation of the Doxapram infusion

An appreciable difference in the time for full recovery to occur was found between patients receiving the analeptic and others who did not Direct clinical observation leaves no doubt that an arousal effect is produced which persists along with the augmented breathing response However, an accelerated recovery from thiopental anaesthesia is not a promunent effect with respect to the expected recovery time because it did not appreciably reduce the total "sleeping time" following a double "sleep dose" of thiopental in humans

\section{Hí́SUMÉ}

A la suite d'expériences croisées chez des chiens, nous avons constaté que le chlorhydrate de doxapram, administré en une seule dose, était aussı efficace que l'amphétamine pour accélérer le révell à la suite d'une anesthésı produite par une dose standard de thiopental et était plus efficace que le phénıdate de méthyl à des doses comparables Au cours de ces expériences, nous miavons pas observé d'effets secondaures

Chez 50 malades en bonne santé, opérées pour dılatatıon et curetage, nous avons employé le chlorhydrate de doxapram en perfusion endoveineuse, nous avons observé une stımulation de la respiration (l'air courant et le rythme) sans changement circulatoire important Chez quatre malades, des signes d'irritation du système nerveux central sont apparus, mars, en arrêtant la perfusion, ils sont disparus rapidement 
Nous avons observé une différence appréciable dans le délaı du révell complet chez les malades quı avaient reçu l'analeptıque et chez ceux qui ne l'avaient pas reçu L'observation clinique directe nous permet d'aftirmer qu'il se produit un réveıl quı persıste et ainsı qu'une augmentation des échanges respıratorres Toutefors, un révell précoce d'une anesthésıe au thiopental ne constitue pas un facteur important sı l'on consıdère le délaı normal prévu pour l\$ réveıl, le médıcament n’a pas dımınué, de façon appréciable, la durée du sommell chez l'humain, à la suite d'une double dose de thiopental

\section{ACIRNOWLEDGMENT}

This study was supported by a grant-in-ald from I/r W $\mathbb{R}$ Tabor of A $H$ Robins Co, Inc, Richmond, Va

\section{REFERENCES}

1 HAHN, F Analeptics Pharmacol Rev 12447 (1960)

2 Dobisin, A B, KeIL, A M, \& Albano, P C Effect of Micoren, Ethamivan and Nikethamide on Thiopental Recovery Anesth \& Analg 4158 (1962)

3 Dobisiv, A B Sedatives, Analgesics, Antdotes and Their Interaction Canad Anaesth Soc J 11252 (1964)

4 Sanchez-Salazar, A A, Pembleton, E W, \& BanerjelE, C M Doxapram Hydrochloride as a Respiratory Stimulant in Anesthetized Man Anesthesiology 24808 (1963)

5 Siker, E S, Mustafa, K, \& Woljeson, B The Analeptid Effects of Doxapram Hydrochloride on Thopentone Induced Depression Brit J Anaesth 36216 (1964)

6 Stephen, C R \& TALton, I Investgation of Doxapram as a Post Anesthetic Respuratory Strmulant Anesth \& Analg 43628 (1964)

7 Aronovitch, M, Karana, L M, Meakins, J F, Place, $\mathbb{R}$ E G, \& Lanne, $R$ Vamillic Diethylamide in the Management of Acute Respiratory [nsufficiency Canad M A J 85875 (1961)

8 Miller, W F, Archer, R K, Taylor, H F, \& Ossenfolit, W E Severe Respiratory Depression J A M A 180905 (1962)

9 CANTER, H G Comparative Study of Three Respiratory Stumulants in Chronic Obstructwe Emphysema Am Rev Resp Dis 87830 (1963)

10 TezFord, J \& KeAts, A S Studies of Analgesic Drugs IX Antagonism of Narcotic Antagonist-Induced Respiratory Depression Chn Pharmicol \& Therap 612 (1965)

11 Rockwell, F H \& Greene, N M Ethamivan and the Ventilatory Response to Carbon Dioxide in Depressed Man Clin Pharmacol \& Therap 4728 (1963)

12 WARD, I W \& Franks, B V A New Centrally Acting Aggent (AHR-619) with Marked Respiratory Stumulating, Pressor and "Awakening" Effect" Fed Proc 21325 (1962)

13 Dobrin, A B, Pearson, J L, \& Barr, J S The Effect of Lysergic Acid Diethylamide (Delysid, LSD-25) on Thiopental Recovery Canad Anaesth Soc J 716 (1960)

14 DoBRn, A B \& WyANT, G M Physiological Effects of Intravenous Anaesthesia Canad Anaesth Soc I 4295 (1957)

15 DOBRIN, A B \& HarLand, J H Drugs which Stumulate Affective Behaviour 1 Action of Lysergic Acid Diethylamide (LSD-25) agamst Thiopentone Anaesthesia in Dogs Anaesthesia 1548 (1960)

16 DoBKIN, A B Drugs which Stumulate Affective Behaviour \& Cornpanson of the Analeptic Effects of d'Amphetamine, Bemignde with Amiphenazole, Methylphenidylacetate, Iproniand, Prethcamid (Micoren) and RP8228 Anaesthesia 15 146 (1960)

17 - Drugs which Stmulate Affective Behaviour 3 Comparison of the Effect of Picrotoxun, Pentylenetetrazol, Bemignde, Prpradol, Ectylurea, Vanilhc Acid Diethylamide and Deanol Anaesthesia 15273 (1960)

18 Bendixen, H H, Hedley-Whyte, J \& LAver, M B Implaired Oxygenation in Surgical Patients duning General Anesthesia with Controlled Venlilation A Concept of Atelectasis New Engl J Med 269991 (1963)

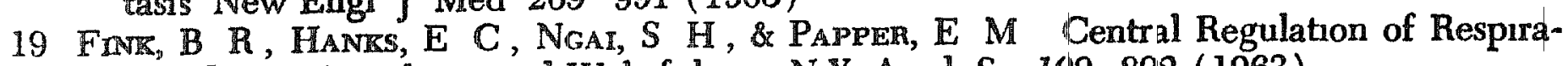
ton during Anesthesia and Wakefulness N Y Acad Sc 1019892 (1963) 